\title{
Nature of Gene Action for Yield and its Contributing Traits in Sponge Gourd (Luffa cylindrica Roem.)
}

\author{
Vijay Bahadur Singh Chauhan ${ }^{1,2} *$, Dinesh Kumar Singh ${ }^{1}$, Harshawardhan \\ Choudhary ${ }^{1,3}$, Venkatraman Bansode ${ }^{2}$ and Kalidas Pati $^{2}$
}

${ }^{1}$ Department of Vegetable Science, Govind Ballabh Pant University of Agriculture and Technology, Pantnagar-263145, U.S. Nagar, Uttarakhand, India

${ }^{2}$ ICAR-Central Tuber Crops Research Institute, Regional Centre, Bhubaneswar-751019, Odisha, India

${ }^{3}$ ICAR-Indian Agricultural Research Institute, New Delhi-110012, India

*Corresponding author

\begin{abstract}
A B S T R A C T
Keywords

Sponge gourd, Luffa cylindrical, Half diallel, Gene action, Yield traits

Article Info

Accepted:

15 November 2018

Available Online:

10 December 2018

The present investigations were carried out to estimate the genetic components of variation for yield and its contributing traits in sponge gourd. Genetic components $\mathrm{D}^{\wedge}, \mathrm{H}^{\wedge}$ and $\mathrm{H}_{2}^{\wedge}$ were significant for days to first male flower anthesis, node number of first male flower, days to first female flower anthesis, node number of first female flower, fruit length, fruit weight, number of fruits per plant, main vine length and total yield except $\mathrm{D}^{\wedge}$ in case of number of primary branches which indicate the importance of both additive and dominant gene effects in regulating these traits. However, higher value of $\hat{\mathrm{H}}_{1}^{\wedge}$ and $\mathrm{H}_{2}{ }_{2}$ compared to $\mathrm{D}^{\wedge}$ for all the traits showed that non-additive gene effect have a greater role than additive gene effects. Significance value of $\mathrm{h}^{\wedge 2}$ for days to first male flower anthesis, days to first female flower anthesis, fruit weight, number of fruits per plant, number of primary branches and total yield. The average degree of dominance $\left(\mathrm{H}_{1}^{\wedge} / \mathrm{D}^{\wedge}\right)$ and ratio of $\mathrm{KD} / \mathrm{KR}$ were more than unity for all the traits showed preponderance of dominant genes in the expression and hence, suggested that hybrid breeding can be used efficiently to improve yield and its contributing traits in sponge gourd.
\end{abstract}

\section{Introduction}

Sponge gourd [Luffa cylindrica (Roem.) L.] is one of the important cucurbitaceous vegetable crops and commonly grown throughout the tropical and sub-tropical region of the world (Kalloo, 1993). Tender fruits of sponge gourd are very popular and well known culinary vegetable in India with good nutritive value and high yield potentials. The fibers of dried fruits are used for industrial purpose as well as a bath sponge which helps in blood circulation and credited as a relief for rheumatic and arthritic suffers (Chauhan, et al., 2012). Tender fruits of sponge gourd are a good source of vitamin A, vitamin $\mathrm{C}$ and iron (Yawalker, 2004). Sponge gourd is highly cross-pollinated crop due to monoecious nature and has a broad spectrum of early maturity, high yielding, fruit weight, fruit 
length and fruit colour and other compositions. For the genetic improvement of crops, one needs to elucidate the genetic nature and magnitude of quantitatively inherited traits and estimate prepotency of parents in combinations (Negi et al., 2013). The direct selection for quality traits in sponge gourd, same as in all other crops, will not be successful due to interaction of many genes with environment. Therefore, the present study is undertaken to understand the nature of gene effects involved in the expression of characters. An assessment of genetic parameters for yield related traits will provide an ample amount of information to the breeder for development of the efficient breeding strategies for improvement in sponge gourd.

\section{Materials and Methods}

The six most promising and diverse genotypes viz., PSG-93, PSG-82, PSG-07-04, PSG-115, PSG-199 and PSG-161 were crossed in $6 \times 6$ half diallel fashion during Kharif, 2007. The resulted 15 hybrids and six parents were evaluated in randomized block design with three replications during summer season 2008 at Vegetable Research Centre of the G.B. Pant University of Agriculture and Technology, Pantnagar, U.S. Nagar, Uttarakhand, India. Each genotype was grown in a single row of 8 $\mathrm{m}$ length with a spacing of $3 \times 1 \mathrm{~m}$.

There were eight hills per entry with one plant at each hill. All the recommended package and practices were followed to grow a successful crop. Observations were recorded on five randomly selected plants from each genotype in each replication for days to first male flower anthesis, node number of first male flower, days to first female flower anthesis, node number of first female flower, fruit length, fruit weight, number of fruits per plant, number of primary branches per plant, main vine length and fruit yield per hectare. The mean values of each genotype were subjected to analysis of variance. The estimation of genetic components of variation was calculated for the analysis of numerical approach followed the method given by Hayman (1954).

\section{Results and Discussion}

The estimates of $\mathrm{D}^{\wedge}, \mathrm{H}_{1}, \mathrm{H}_{2}, \mathrm{~F}^{\wedge}$ and $\mathrm{E}^{\wedge}$ parameters along with its components obtained from half diallel analysis were presented in Table 1. The estimates of additive (D) genetic variance was positive and significant for days to first male flower anthesis, node number of first male flower, days to first female flower anthesis, node number of first female flower, fruit weight, main vine length and total yield indicating high transmissibility in the progeny. Therefore, direct selection will be of much use for these traits which is accordance with finding of Khule et al., (2011), Narasannavar et al., 2012 and Sharma et al., (2017) in sponge gourd.

The estimates of components of variation due to dominance $\left(\mathrm{H}_{1}\right)$ and proportion of dominance due to positive and negative gene $\left(\mathrm{H}_{2}\right)$ exhibited higher importance of nonadditive gene effects than additive gene effects for days to first male flower anthesis, node number of first male flower, days to first female flower anthesis, node number of first female flower, fruit length, fruit weight, number of fruits per plant, number of primary branches, main vine length and total yield which showed preponderance of dominance effects in the inheritance of yield and its contributing traits.

Kumar et al., (2018) also observed that the both additive and dominance variance were found important in the inheritance of most of the traits, whereas dominance variance were more prominent than the additive variance. Average degree of dominance revealed the 
presence of over dominance for all traits. Highly significant values of additive $\left(\mathrm{D}^{\wedge}\right)$ and dominance $\left(\mathrm{H}_{1}\right.$ and $\left.\hat{\mathrm{H}}_{2}\right)$ effects of components were observed for most of the traits studied except the values of $\mathrm{D}^{\wedge}$ for node number to first male flower appearance, number of primary branches per plant and for days to first male flower anthesis in pumpkin. Preponderance of non-additive gene action in inheritance of yield and its contributing traits were also reported by Singh et al., (2018) and Sanandia et al., (2010) in sponge gourd.

The estimates of $\mathrm{H}_{1}$ and $\hat{\mathrm{H}}_{2}$ were unequal for days to first male flower anthesis, node number of first male flower, days to first female flower anthesis, node number of first female flower, fruit length, fruit weight, number of fruits per plant, main vine length and total yield indicating thereby unbalanced distribution of dominance and recessive alleles while almost similar estimate of these two showed balanced distribution of both dominant and recessive alleles in case of number of primary branches.

However, the positive and significant estimate of both $\mathrm{H}_{1}$ and $\mathrm{H}_{2}$ reflected the effects of dominance gene in favorable as well as in positive direction for the all the traits under the studied. Similar trends were also confirmed by Gautam and Yadav (2017) in bottle gourd.

The $\mathrm{F}^{\wedge}$ value were positive for the all the traits under studied and significant for days to first male flower anthesis, days to first female flower anthesis and fruit weight which showed that dominant alleles were more frequent than recessive alleles in the parents accordance with Kumar et al., (2018). Significance value of $\mathrm{h}^{\wedge}$ for days to first male flower anthesis, days to first female flower anthesis, fruit weight, number of fruits per plant, number of primary branches and total yield revealed that important effects of heterozygous loci in the expression of these traits. The average degree of dominance $\left(\mathrm{H}_{1}^{\wedge} / \mathrm{D}^{\wedge}\right)^{1 / 2}$ involved in the action of gene was observed greater than unity for the all the traits under the studied which indicated that presence of over-dominance for these traits and therefore, it is suggested that heterosis breeding might be advantageous for improvement of yield and contributing traits in sponge gourd. These findings are in conformity with Ray et al., (2015) in bottle gourd.

The $\mathrm{H}_{2} / 4 \mathrm{H}_{1}$ was not equal to the 0.25 for the most of the traits except number of primary branches confirmed the asymmetrical distribution of dominance and recessive genes among the parents as also observed in the estimate of $\mathrm{F}$. This was in general accordance with the finding of Gautam and Yadav (2017) in bottle gourd.

The ration of dominance and recessive alleles $(\mathrm{KD} / \mathrm{KR})$ i.e. $\left[\left(4 \mathrm{D}^{\wedge} \mathrm{H}_{1}{ }_{1}\right)^{1 / 2}+\left(4 \mathrm{D}^{\wedge} \mathrm{H}_{1}\right)^{1 / 2}-\mathrm{F}^{\wedge}\right]$ was observed more the unity for the all the traits under studied, showed the majority of dominant alleles and minority of recessive alleles among the parental strain for days to anthesis of first male flower, node number of first male flower, days to anthesis of first female flower, node number of first female flower, fruit length, fruit weight, number of fruits per plant, number of primary branches per plant, main vine length and total yield. The higher proportion of dominant genes observed for the most of the traits are in agreement with the finding of Kumar et al., (2018).

The value of $\mathrm{h}^{\wedge} / \mathrm{H}_{2}$ was less than unity for the most of the traits except number of fruits per plant and total yield reflected the one major gene group involved for most of the traits, which may be due to conceding effects of dominant genes with positive and negative effects nullify the effects of other. These finding are in agreement with Gautam and Yadav (2017). 
Table.1 Estimates of genetic components of variation and their ratio for different traits in sponge gourd

\begin{tabular}{|c|c|c|c|c|c|c|c|c|c|c|}
\hline $\begin{array}{l}\text { Components } \\
\text { of variation }\end{array}$ & $\begin{array}{l}\text { Days to } \\
\text { first male } \\
\text { flower } \\
\text { anthesis }\end{array}$ & $\begin{array}{l}\text { Node } \\
\text { number of } \\
\text { first male } \\
\text { flower }\end{array}$ & $\begin{array}{l}\text { Days to } \\
\text { first } \\
\text { female } \\
\text { flower } \\
\text { anthesis }\end{array}$ & $\begin{array}{l}\text { Node } \\
\text { number of } \\
\text { first } \\
\text { female } \\
\text { flower }\end{array}$ & $\begin{array}{l}\text { Fruit } \\
\text { length } \\
\text { (cm }\end{array}$ & $\begin{array}{l}\text { Fruit } \\
\text { weight (g) }\end{array}$ & $\begin{array}{l}\text { Number } \\
\text { of fruits } \\
\text { per plant }\end{array}$ & $\begin{array}{l}\text { Number of } \\
\text { primary } \\
\text { branches }\end{array}$ & $\begin{array}{l}\text { Main vine } \\
\text { length (m) }\end{array}$ & $\begin{array}{l}\text { Total } \\
\text { yield } \\
\text { (q./ha.) }\end{array}$ \\
\hline $\mathbf{D}^{\wedge}$ & $\begin{array}{l}50.81 * * \\
+-9.13\end{array}$ & $\begin{array}{l}6.63 * * \\
+-2.82\end{array}$ & $\begin{array}{l}77.79 * * \\
+-17.35\end{array}$ & $\begin{array}{l}28.71 * * \\
+-8.12\end{array}$ & $\begin{array}{l}2.21 \\
+-2.68\end{array}$ & $\begin{array}{l}2601.16 * * \\
+-542.97\end{array}$ & $\begin{array}{l}4.81 \\
+-5.42\end{array}$ & $\begin{array}{l}0.19 \\
+-0.33\end{array}$ & $\begin{array}{l}0.43 * \\
+-0.21\end{array}$ & $\begin{array}{l}245.63 * \\
+-183.01\end{array}$ \\
\hline $\mathbf{H}_{1}^{\wedge}$ & $\begin{array}{l}119.95^{* *} \\
+-23.18\end{array}$ & $\begin{array}{l}19.22 * * \\
+-7.16\end{array}$ & $\begin{array}{l}199.77 * * \\
+-44.06\end{array}$ & $\begin{array}{l}63.82 * * \\
+-20.62\end{array}$ & $\begin{array}{l}15.25^{* *} \\
+-6.81\end{array}$ & $\begin{array}{l}8018.09 * * \\
+-1378.39\end{array}$ & $\begin{array}{l}61.02 * * \\
+-13.76\end{array}$ & $\begin{array}{l}2.52 * * \\
+-0.83\end{array}$ & $\begin{array}{l}1.66 * * \\
+-0.53\end{array}$ & $\begin{array}{l}2978.57 \text { ** } \\
+-464.58\end{array}$ \\
\hline $\mathbf{H}_{2} \hat{2}$ & $\begin{array}{l}88.47 * * \\
+-20.71\end{array}$ & $\begin{array}{l}14.44 * * \\
+-6.39\end{array}$ & $\begin{array}{l}147.31 * * \\
+-39.36\end{array}$ & $\begin{array}{l}46.16 * * \\
+-18.42\end{array}$ & $\begin{array}{l}11.54^{*} \\
+-6.08\end{array}$ & $\begin{array}{l}6390.26 * * \\
+-1231.35\end{array}$ & $\begin{array}{l}47.86 * * \\
+-12.29\end{array}$ & $\begin{array}{l}2.43 * * \\
+-0.74\end{array}$ & $\begin{array}{l}1.01 * \\
+-0.47\end{array}$ & $\begin{array}{l}2590.55^{* *} \\
+-415.02\end{array}$ \\
\hline $\mathbf{F}^{\wedge}$ & $\begin{array}{l}60.10 * * \\
+-22.31\end{array}$ & $\begin{array}{l}5.56 \\
+-6.89\end{array}$ & $\begin{array}{l}95.56 * * \\
+-42.40\end{array}$ & $\begin{array}{l}25.53 \\
+-19.84\end{array}$ & $\begin{array}{l}2.05 \\
+-6.55\end{array}$ & $\begin{array}{l}3487.87 * * \\
+-1326.48\end{array}$ & $\begin{array}{l}12.86 \\
+-13.24\end{array}$ & $\begin{array}{l}0.12 \\
+-0.80\end{array}$ & $\begin{array}{l}0.90 \\
+-0.51\end{array}$ & $\begin{array}{l}143.71 \\
+-447.08\end{array}$ \\
\hline$h^{\wedge}$ & $\begin{array}{l}44.79 * * \\
+-13.94\end{array}$ & $\begin{array}{l}4.42 \\
+-4.30\end{array}$ & $\begin{array}{l}78.40 * * \\
+-26.49\end{array}$ & $\begin{array}{l}11.30 \\
+-12.40\end{array}$ & $\begin{array}{l}6.49 \\
+-4.09\end{array}$ & $\begin{array}{l}1246.93 * * \\
+-828.78\end{array}$ & $\begin{array}{l}76.85 * * \\
+-8.27\end{array}$ & $\begin{array}{l}1.26 * * \\
+-0.50\end{array}$ & $\begin{array}{l}0.26 \\
+-0.32\end{array}$ & $\begin{array}{l}5465.08 * * \\
+-279.34\end{array}$ \\
\hline $\mathbf{E}^{\wedge}$ & $\begin{array}{l}1.17 \\
+-3.45\end{array}$ & $\begin{array}{l}0.06 \\
+-1.07\end{array}$ & $\begin{array}{l}2.28 \\
+-6.56\end{array}$ & $\begin{array}{l}0.56 \\
+-3.07\end{array}$ & $\begin{array}{l}0.30 \\
+-1.01\end{array}$ & $\begin{array}{l}47.70 \\
+-205.22\end{array}$ & $\begin{array}{l}1.50 \\
+-2.05\end{array}$ & $\begin{array}{l}0.07 \\
+-0.12\end{array}$ & $\begin{array}{l}0.08 \\
+-0.08\end{array}$ & $\begin{array}{l}19.27 \\
+-69.17\end{array}$ \\
\hline$\left(H^{\wedge}{ }_{1} / D^{\wedge}\right)^{1 / 2}$ & 1.54 & 1.7 & 1.60 & 1.49 & 2.62 & 1.76 & 3.56 & 3.68 & 1.96 & 3.48 \\
\hline$\left(\hat{H}_{2} / 4 \mathbf{H}_{1}\right)$ & 0.18 & 0.19 & 0.18 & 0.18 & 0.19 & 0.20 & 0.20 & 0.24 & 0.15 & 0.22 \\
\hline (KD/KR) & 2.25 & 1.65 & 2.24 & 1.85 & 1.43 & 2.24 & 2.20 & 1.19 & 3.29 & 1.18 \\
\hline$\left(\mathbf{h}^{\wedge} \mathbf{2} / \mathbf{H}_{2}{ }^{\prime}\right)$ & 0.51 & 0.31 & 0.53 & 0.24 & 0.56 & 0.20 & 1.61 & 0.52 & 0.26 & 2.11 \\
\hline
\end{tabular}


In the present study, genetic components $\mathrm{D}^{\wedge}$, $\mathrm{H}_{1}$ and $\hat{\mathrm{H}}_{2}$ were significant for days to anthesis of first male flower, node number of first male flower, days to anthesis of first female flower, node number of first female flower, fruit length, fruit weight, number of fruits per plant, main vine length and total yield except $\mathrm{D}^{\wedge}$ in case of number of primary branches which indicate the importance of both additive and dominant gene effects in regulating these traits. However, higher estimate value of $\mathrm{H}_{1}$ and $\mathrm{H}_{2}$ compared to $\mathrm{D}^{\wedge}$ for all the traits showed that non-additive gene effect have a greater role than additive gene effects. The positive estimate of dominance components $\left(\mathrm{H}_{1}^{\wedge}\right.$ and $\left.\mathrm{H}_{2}^{\wedge}\right)$ indicated that the dominance genes were in the favorable and positive direction for all the traits. Significance value of $\mathrm{h}^{\wedge}$ for days to first male flower anthesis, days to first female flower anthesis, fruit weight, number of fruits per plant, number of primary branches and total yield revealed that important effects of heterozygous loci in the expression of these traits. The average degree of dominance $\left(\mathrm{H}_{1}^{\wedge} / \mathrm{D}^{\wedge}\right)^{1 / 2}$ involved in the action of gene was observed greater than unity for the all the traits under the studied which indicated that presence of over-dominance. The ratio of $\mathrm{KD} / \mathrm{KR}$ was more than unity for all of the traits signifying the excess of dominant genes than recessive among the parents. Present revealed that both additive and non-additive genetic components were important in the inheritance of the yield and its components with preponderance of non-additive gene action. It is therefore suggested that hybrid breeding can be used efficiently to improve the yield and its contributing traits in sponge gourd.

\section{References}

Chauhan, V.B.S., Singh, D.K. and Choudhury, H. (2012). Biochemical characterization of parental lines and F1 hybrids in smooth gourd (Luffa cylindrica Roem.). Vegetable Science, 39 (1): 105-107.

Gautam, D.K. and Yadav, G.C. (2017). Gene action for growth, yield and quality traits in bottle gourd [Lagenaria siceraria (Mol.) Standl]. Journal of Pharmacognosy and Phytochemistry, 6(4): 84-88.

Hayman, B.I. (1954). The theory and analysis of diallel crosses. Genetics, 39: 789809.

Kalloo, G. (1993). Loofah-luffa spp. In: Genetic Improvement of Vegetable Crops. Pergamon Press, pp. 265-266.

Khule, A.A., Tikka, S.B.S., Jadhav, D.J. and Kajale, D.B. (2011). Genetic variability and heritability studies in local collections of sponge gourd [Luffa Cylindrica (Linn.) M. Roem ]. Asian Journal of Bio Science; 6(1): 119-120.

Kumar, V., Mishra, D.P., Yadav, G.C. and Babu, U. (2018). Studies on genetic component analysis and gene action for growth, yield and yield attributing traits of pumpkin. International Journal of Chemical Studies, 6(2): 2695-2699.

Narasannavar, A., Devappa, V., Fakrudin, B., Pitchaimuthu, M. and Sriram, S. (2018). Gene action and heterosis studies for growth, earliness, yield and downy mildew disease [Pseudoperonospora cubensis (Berk. and Curt.) Rostow.] in Ridge Gourd [Luffa acutangula (Roxb.) L.]. Int. J. Curr. Microbiol. App. Sci., 7(2): 3533-3542.

Negi, P.K., Sharma, R.R., Kumar, R. and Chauhan, V.B.S. (2013). Genetic analysis for yield and its contributing traits in tomato under low temperature regime. Vegetable Science, 40 (2): 189194.

Ray, P.K., Yadav, G.C., Baranwal, D.K. and Singh, H.K. (2015). Genetic estimates and gene action for obtaining promising heterotic hybrids in bottle gourd 
[Lagenaria siceraria (molina) standl.]. The Bioscan, 10(2): 801-806.

Sanandia, S.T., Mehta, D.R. and Gajipara, N.N. (2010). Genetic study for earliness in sponge gourd [Luffa cylindrica (Roem.) L.]. The Asian Journal of Horticulture, 5(1): 64-66.

Sharma, N., Bisen, B.P., Bisen, R. and Verma, B. (2017). Genetic variability, correlation and path analysis in sponge gourd genotypes in Kymore plateau.
Green Farming, 8(2): 301-305.

Singh, Y.P., Singh, V. B., Kumar, A. and Pramila (2018). Studies on general and specific combining ability for yield and its contributing traits in sponge gourd [Luffa cylindrica (Roem) L.]. Int. J. Curr. Microbiol. App. Sci, Special Issue-7: 5066-5078.

Yawalkar, K.S. (2004). Cucurbitaceous or vine crops. Vegetable Crops of India (V Ed.), pp. 152-155.

\section{How to cite this article:}

Vijay Bahadur Singh Chauhan, Dinesh Kumar Singh, Harshawardhan Choudhary, Venkatraman Bansode and Kalidas Pati. 2018. Nature of Gene Action for Yield and its Contributing Traits in Sponge Gourd (Luffa cylindrica Roem.) Int.J.Curr.Microbiol.App.Sci. 7(12): 2201-2206. doi: https://doi.org/10.20546/ijcmas.2018.712.250 